\title{
Crowdfunding as an Alternative Mode of Financing Micro and Small Enterprises: A Proposed Qard-al-Hasan Contract
}

\author{
Abdulmajeed M.R. Aderemi \\ Universiti Sultan Zainal Abidin, Malaysia \\ Corresponding email: majeedity@gmail.com \\ Muhammad Shahrul Ifwat bin Ishak \\ Universiti Sultan Zainal Abidin, Malaysia \\ Article History \\ Received: June $6^{\text {th }}, 2020$ Revised: August $8^{\text {th }}, 2020$ Accepted: August $30^{\text {th }}, 2020$
}

\begin{abstract}
The global financial crisis that occurred in 2008, coupled with the evolution and globalization of social media and technology has made the evolvement of crowdfunding easy to use as a means of financing. However, the concept of crowdfunding is correlated with spiritual and religious responsibility which can increase the economic growth of Micro and Small Enterprises. In light of this, this paper aims to investigate the capacity of crowdfunding and proposes a crowdfunding model that adheres to the principle of Shari'ah by adopting a legitimate contract known as Qard-al-Hasan. In this regard, the study adopts a qualitative research using secondary data with descriptive, and inductive approaches in analysis. The result shows that Qard-al-Hasan based crowdfunding is great for pioneering business people to get access to financing their small and micro enterprises in compliance with Shariah. However, the findings of this paper will provide a new mechanism for financing micro and small enterprises in line with Shariah.
\end{abstract}

Keywords: Crowdfunding, Qard-al-Hasan, Micro and Small Enterprises.

JEL Classifications: P43, O36, D64, L25.

@ IJIEF 2020 published by Universitas Muhammadiyah Yogyakarta, Indonesia

All rights reserved

DOI:

Web:

https://doi.org/10.18196/ijief.3235 https://journal.umy.ac.id/index.php/ijief/article/view/8968

Citation:

Aderemi, A. M. R., \& Ishak, M. S. I. (2020). Crowdfunding as an alternative mode of financing micro and small enterprises: A proposed Qard-al-Hasan contract. International Journal of Islamic Economics and Finance (IJIEF), 3(2). 95-118. DOI: https://doi.org/10.18196/ijief.3235 
Aderemi \& Ishak | Crowdfunding as an Alternative Mode of Financing Micro and Small Enterprises: A Proposed Qard-Al-Hasan Contract

\section{Introduction}

\subsection{Background}

One of the fundamental part of economic segment are small and medium enterprises, it contributes greatly- as a driven force- to the nationwide economy, it also helps to mitigate poverty as well as it serves as a resistant to the catastrophes. If SMEs is well managed by a country it can creates jobs, increase revenue, lessen vulnerability and escalate investment in human resources (Hendratmi, Sukmaningrum, Ryandono \& Ratnasari, 2019). According to the report from World Bank (2018) not less down 90\% of businesses worldwide are represented by SMEs as well as about $50 \%$ of employment are created universally. Additionally, in developing economies countries $40 \%$ of national income (GDP) are contributed by formal SMEs.

Total Credit Gap - Formal and Informal Enterprises is \$2.1-2.6 Trillion

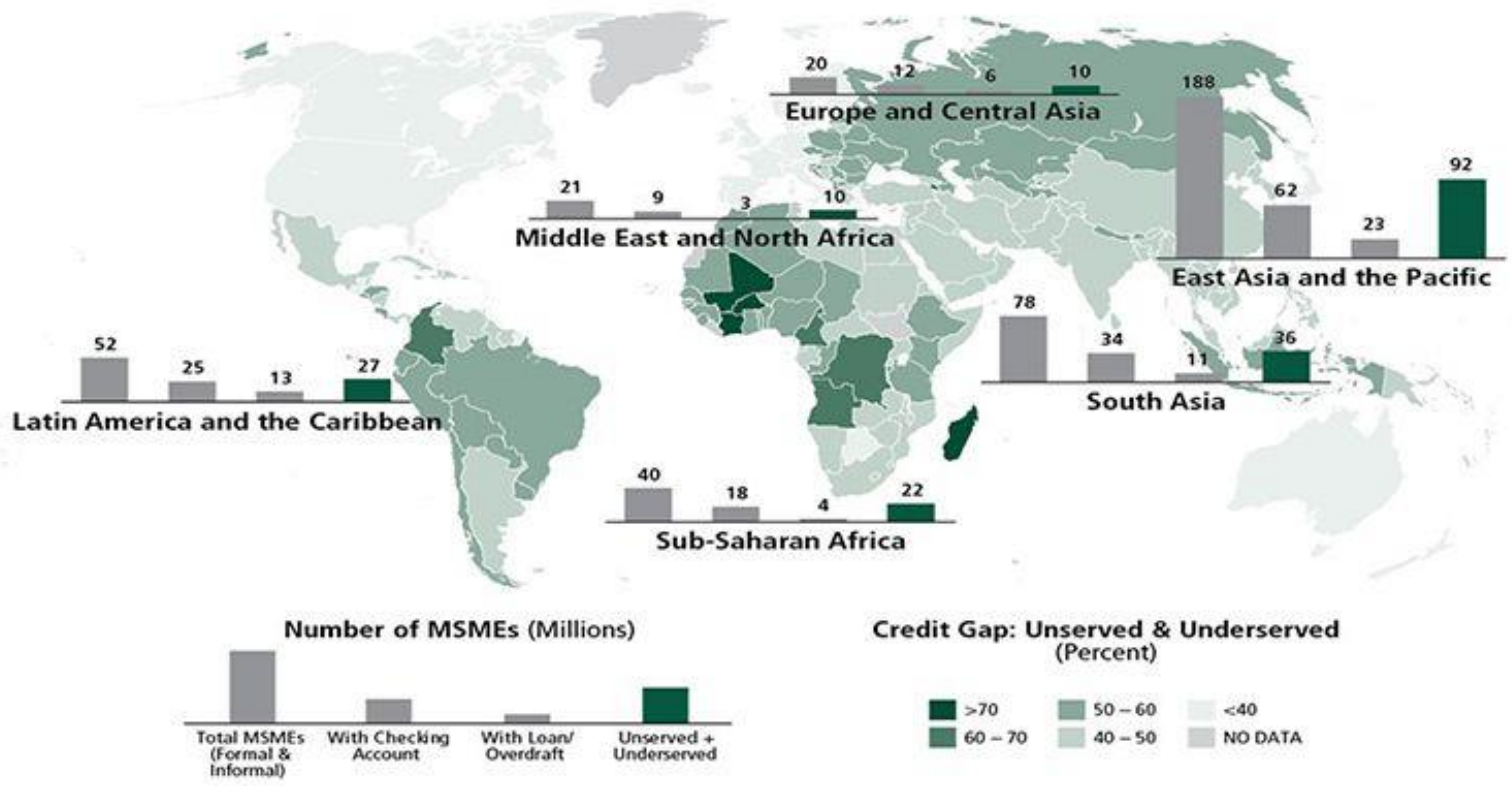

Figure 1. Total credit gap

Source: (World Bank, 2018)

Ironically, even though this sector has significantly influenced the economy, a substantial sum of empirical studies show that SMEs still going through financial constraints to establish, nurture and sustain their businesses as shown in the figure above, this financial constriction remains one of the greatest significant problem for their existence, development, and productivity (Owens \& Wilhelm, 2017). It was reported that in the world's 
Aderemi \& Ishak | Crowdfunding as an Alternative Mode of Financing Micro and Small Enterprises: A Proposed Qard-Al-Hasan Contract

emerging markets, out of 400 million approximated SMEs, 180 to 220 million SMEs, still going through unmet credit needs adding up between US\$2.1 to US\$2.6 trillion as shown in figure 1 above.

The 2008 global financial crises cause extra challenges for SMEs to obtain a loan from bank by raising loan requirement, limiting loan and increasing interest rates. However, the unapproachability to financial services can therefore make the economy to undergo a sequence of negative significances inclusive of restriction of economics and social opportunities (Hendratmi, Sukmaningrum, Ryandono, \& Ratnasari, 2019). Apparently, for the SMEs to completely unleash their potential in other to contribute inclusively to the growth of economy, access to a variety of financial mechanism is compulsory.

In spite of these funding difficulties, or for the reason of these difficulties, a new method for obtaining capital has arisen in response to the present ineffective institutionalized capital markets known as crowdfunding, crowdfunding emerged and got attention of entrepreneurs as a result of the evolution and globalization of social media and technology (Boylan, Nesson \& Philipps, 2018), the idea of crowdfunding implicates utilizing the Internet together with the power of the mass to accumulate capital in an open and transparent way (Beaulieu, Sarker \& Sarker, 2015). As a consequence, for the purpose of aiding the growth of business, entrepreneurs are on the go to exploit crowdfunding for capitals assembling worldwide and it has become an alternative to banks and financial institutions (Lambert \& Schwienbacher, 2010), therefore, it has developed a vast potential to reduce the tiresome procedure of bank loan request from SMEs (Rahim, Kasmon \& Taslim, 2018).

Most of the platform of Islamic crowdfunding are currently using Mudarabah(silent partnership) and Murabahah (Cost-plus Financing) contracts (Hendratmi et al., 2019), However, study has shown that there is an increment in sales productivity, assets and the efficiency of Micro, Small and Medium Enterprises (MSMEs) and startup businesses that received finance through these platforms (Hendratmi et al., 2019), hence more platforms and models is needed in order to fill these gaps. Islamic crowdfunding should be considered as the next financial innovation in Islamic Finance, with various Shari'ah based models can be suggested. These include Zakat-based model, Infaq-Sadaqa-Waqf-based model, Qard alHasan-based model, and Shrikah-based model. As for lending-based model, Murabahah, ljarah, and Istishna' can be developed as its instrument. Nevertheless, Islamic crowdfunding mechanisms are still facing some 
Aderemi \& Ishak | Crowdfunding as an Alternative Mode of Financing Micro and Small Enterprises: A Proposed Qard-Al-Hasan Contract

problems, including to develop relevant crowdfunding models for SMEs (Hassan, 2017). Also, there is still no a clear theoretical framework that can guide Islamic crowdfunding start up (Hanim, Zurina \& Muhammad, 2018). Thus, it can be concluded that the current Islamic crowdfunding practices need to be improved, particularly by exploring various Shari'ah contracts that can strengthen its framework.

In this regard, this research considers other structure of which is Qard-alHasan contract. Qard-al-Hasan is a virtuous loan giving out with the clause of returning the principal sum to the owner in the same condition without any increase in the stipulated time (Ariffin \& Adnan, 2012). This Qard-al-Hasan based crowdfunding is proposed in order to improve the economic life of the financing participants. Therefore, the theme of this study is to endorse Qardal-Hasan as the income generation through business financing as it applies interest-free contract. Meanwhile, crowdfunding is employed as the mechanism for fundraising, merging both Qard-al-Hasan and crowdfunding which complies with Shariah may become an alternative solution to the financial challenges facing by micro and small enterprises. The scope of this study is to explore the application of Qard-al-Hasan on crowdfunding in filling the financial gap facing the Micro and Small Enterprises, therefore, the researcher will focus on applicability of Islamic crowdfunding using Qard-alHasan contract as a better and ethical alternative for mitigating the financial constraint facing the Micro and Small Enterprises.

\subsection{Objective}

This study aims to explore the potential of Islamic crowdfunding as an alternative financing for micro and small enterprises, as a regard this study attempt to propose a crowdfunding model using Qard-al-Hasan contract as a viable alternative funding source for micro and small enterprises which is free from usury contract and equally reachable to numerous groups of people.

The discussion of this paper is organized into five sections, firstly it presents a general introduction which comprises background and objective of the study, secondly it presents literature review where background theory, previous studies and conceptual framework were elaborated, thirdly it discusses the methodology of the study. Fourthly it presents the results and analysis, and the last section concludes the paper with limitation and some recommendations. 
Aderemi \& Ishak | Crowdfunding as an Alternative Mode of Financing Micro and Small Enterprises: A Proposed Qard-Al-Hasan Contract

\section{Literature Review}

\subsection{Background Theory}

\subsubsection{Theory of Charitable Giving}

A theory of charitable giving, is a theory that concentrates most on the factors influencing the decision of donors either it is pure or impure humanitarianism. Andreoni (2006) asserted that the economic theory of charitable giving, differentiates between impure altruism and pure altruism. According to Ly \& Mason (2012) pure altruism is the practice of unselfish concern for the welfare of others and it is about human being's devotion to make contribution to the benefit of the public and placing the outcome of charity on a high value, such as making the welfare of less privileged beneficiaries more better, On the other hand, personal contribution of the donors may be also what they care about, for the reason that utility will be derived for them from donating, which simply indicates that donations may be for both private and public goods.

Additionally, Ly \& Mason (2012) argue that donors may not care only about their own contribution or the overall outcome, but rather care about how the outcome is been achieved. Furthermore, while discussing people's support to development groups or organizations, the fact that donors may be inspired by a general poverty-eradication cause and some pleasure of benevolent is not enough to comprehend their desire. Similarly to this, Bilodeau \& Slivinski (1997) argue that among what donors may take into consideration is the way donations funds is allocate across different ventures, which may lead to a tendency of donations to specialize.

Based on this, Like charitable giving, lending via Qard al-Hasan crowdfunding platforms may reflect a mix of pure and impure altruism, then if poverty eradication, contributing to the betterment of the society and enhancing the welfare of less-privileged beneficiaries by funding their micro and small businesses is an important objective for lenders, they may pursue to make a change by aiming borrowers they observe at the underprivileged and most helpless, to get the best out of the impact of their involvement. The choices of donors may disclose significant aspects of their inclination. Foremost, so far there is no interest to be offered in return, it is rational to conclude that individuals who donate on this platform to a certain campaign express benevolent preferences. 
Aderemi \& Ishak | Crowdfunding as an Alternative Mode of Financing Micro and Small Enterprises: A Proposed Qard-Al-Hasan Contract

\subsection{Previous Studies}

Among the earliest studies Achsien \& Purnamasari ( 2012) In their study they manifested crowdfunding into five models based on Shari'ah Contract: (1) Zakat-based model (2) Infaq-Sadaqa-Waqf-based model, (3) Qard-al-Hasanbased model, (4) Shrikah-based model (Mudarabah and Musharakah) and (5) Lending -based model (Murabahah, Ijarah, Istishna, etc.), he concluded that Islamic crowdfunding, still in the starting point of its maturity and therefor adequate awareness and proper understanding concerning Islamic crowdfunding still poor, hence regulation must be put in place in the nearest future.

However, most closely related study conducted by Marzban et al. (2014) who in their study proposed a Shari'ah-compliant crowdfunding based on convectional crowdfunding models as well as potential beneficiary for each proposed model. As for donation-based crowdfunding they proposed three possible instrument that could be of perfect Islamic charity to use which are Hiba, Qard-al-Hasan, and finally Murabahah, sale instrument would be suitable for reward-based model, Murabahah and ljarah could be more appropriate instrument to be employed for lending-based model while Diminishing Musharakah and Musharakah are prefer for equity-based model, he concluded that the combination of main principles of Shariah, crowdfunding, globalization, and developments the technology signify an opportunity to significantly contribute to the improvement of the business ecosystem in Islamic countries.

Subsequently, Wahjono et al. (2015) in their research stressed that Musharakah and Qard are the most Islamic crowdfunding appropriate models in the sense that Islamic crowdfunding Musharakah-based are designed for the purpose of investment whereas Islamic crowdfunding Qardbased is meant to finance a projects with a loan which has to be refund at given time. Additionally, Lutfi \& Ismail (2016) conducted their study and proposed Sadaqah based crowdfunding for microfinancing and health care, they come to conclusion that the proposed model will serve as a platform to finance entrepreneurial projects through the concept of microfinance and also help create a relief fund for health care treatment. the model proposed uses Shari'ah contracts, namely Sadaqah and Qard al-Hasan. However, Qard al-Hasan was not fully explained in this study. Contextually, Hanim et al. (2018) in their study declared that in Islamic crowdfunding startup there is still no theoretical framework that can guide it. He further emphasis that Islamic crowdfunding are also under-exploration of study on what type of

International Journal of Islamic Economics and Finance (IJIEF), 3(2), SI, 95-118 |100 
Aderemi \& Ishak | Crowdfunding as an Alternative Mode of Financing Micro and Small Enterprises: A Proposed Qard-Al-Hasan Contract

crowdfunding features would be in favor of the potential contributor and the behavior of the contributor.

Similarly, Saiti et al. (2018) proposed two different Islamic P2P models, namely Mudarabah (equity-based) and Murabahah (sale-based) based crowdfunding models. He suggested that future research should explore Islamic crowdfunding further and in greater depth since the resources of these particular issues are limited whereas its potential is significant. Thaker, (2018) categorized Islamic crowdfunding into four models in accordance to mainstream models: Sadaqa-based crowdfunding for Donation-based convectional crowdfunding, Murabahah-based crowdfunding stand for peerto-peer convectional crowdfunding, Mudarabah-based crowdfunding as equity-based convectional crowdfunding and lastly Hiba-based crowdfunding represent reward-based conventional crowdfunding.

The success of Qard al-Hasan has been proven in a study conducted by Febianto \& Ashany (2012) that Qard al-Hasan financing can improve the business of MSMEs successfully and can be potentially advanced further to develop the society's economy especially the poor. However, this study aims to explore the applicability of Qard al-Hasan on crowdfunding as a viable alternative to fund micro and small scale enterprises, to the best knowledge of researcher and based on the reviewed literature, most of the previous studies focused majorly on suggesting the Islamic Contracts that could suit crowdfunding and little research has been carried out on exploring Qard alHasan crowdfunding.

\subsection{Conceptual Framework}

\subsubsection{Crowdfunding}

Definition

One of the first definition of crowdfunding was that of Ordanini et al. (2011) they defined it as an activity attempted to raise fund for a new proposed project by gathering little to medium-size speculation from a few other individual. Nonetheless, Schwienbacher \& Larralde (2012) give the definition based on its characteristic he defined it "as an internet mode of funding by public to the capital or entrepreneurs who are seeking for investment for the motive of expecting reward or pure charity. This definition indicates and add another point which is the form of crowdfunding, it stresses that the motive 
Aderemi \& Ishak | Crowdfunding as an Alternative Mode of Financing Micro and Small Enterprises: A Proposed Qard-Al-Hasan Contract

behind investing in crowdfunding could not only be for the monetary reward, but also could be for the pleasure or fun of doing the particular task i.e. investing".

Models of Crowdfunding

Based on founders, backers, outcome and benefit, crowdfunding can be categorized into four types/models namely: (1) Donation based crowdfunding; (2) Reward based crowdfunding; (3) Lending based crowdfunding; and (4) Equity based crowdfunding (Massolution, 2015).

Donation-based crowdfunding is a mechanism in which the collection of funds occurs for philanthropic or social or other motive without expecting any compensation in return (monetary or not) (Marzban, Asutay \& Boseli, 2014). While Reward-based crowdfundng is a crowdfunding model where investors or backers receive an appreciation for financing an initiative as a token reward such as receiving aknowledgement, gift, or being provided with the products he supported (Thaker, Thaker \& Pitchay, 2018).

On the hand, Lending-based crowdfunding is an internet-enabled platform where lenders or investors choose to lend money to the borrowers or founders in exchange for lower interest which is set by the platform (Thaker, Mohammed, Duasa \& Abdullah, 2016). While Equity-based crowdfunding is an online platform in which funders obtain reward (financial return) in the form of fundraiser's equity-based income or profit-share arrangements (Wilson \& Testoni, 2014). Equity-based crowdfunding is developing as an progressively important source of entrepreneurial financing (Kshetri, 2018).

\subsubsection{Micro, Small and Medium Enterprises (MSMEs) and Its Role in Economy}

The meaning or classification of micro small and medium enterprises varies from country to country. Universally, there is no definition or classification of MSMEs that is agreed on. Different writers, researchers and institutes have various thoughts as to differences in terms of principal expenses, sales, the number of employees' turnover, available plant and machinery, fixed capital investment, the share of market as well as the level of progress (Dar, Ahmed \& Raziq, 2017). In a developed country like the U.S.A, Britain and other European countries, Small and medium scale enterprises are defined with regard to income and number of workers. The European Commission classifies MSMEs as any businesses who have what not less than 250 
Aderemi \& Ishak | Crowdfunding as an Alternative Mode of Financing Micro and Small Enterprises: A Proposed Qard-Al-Hasan Contract

workers, self-governing (with 25\% shareholding at maximum) and with an annual income of at most $£ 50$ million or annual budget of $£ 43$ million (Oyedepo, Duan, Bentley, \& He, 2016).

In Asia, descriptions of MSMEs are dissimilar from one country to another. The gauge for the classification of MSMEs in some countries is capital, while in another it is has to do with the number of workers, and other states use diverse criteria such as Japan, and it varies in each business (Yoshino, 2016). In Malaysia for example MSMEs is divided into three core sectors like manufacturing, common business, and agriculture. In Malaysia, in accordance with Small and Medium Enterprises Corporation Malaysia (SMECORP, 2008), any business that hire full time workers within the range of 50-150 are treated as medium whereas those that hire full time workers within the range of 5-50 are considered as small and anything less than 5 workers are categorized to be micro enterprises ( Khalique, Isa, Nassir Shaari \& Ageel 2009). Subsequently, In Sub-Saharan Africa the classification of SMEs is based on capital employed, income and number of workers (Gbandi \& Amissah, 2014). In Nigeria according to Gbandi \& Amissah (2014), any business that has an asset base (exclusive of land) within the range of N5 million to N500 million and labor force within the range of 11 and 300 said to be Small and Medium enterprises.

Micro, Small and medium enterprises (MSMEs) are said to be the most significant pillar for the growing and development of all economics across the globe (Bagh, Arif, Liaqat, \& Razzaq, 2017). In accordance to the World Bank (2018) not less down $90 \%$ of businesses worldwide are represented by SMEs as well as about $50 \%$ of employment are created universally. Additionally, in developing economies countries $40 \%$ of national income (GDP) are contributed by formal SMEs. it contributes greatly- as a driven force- to the nationwide economy, it also helps to mitigate poverty as well as it serves as a resistant to the catastrophes. If SMEs is well managed by a country it can creates jobs, increase revenue, lessen vulnerability and escalate investment in human resources.(Hendratmi et al., 2019). In fact, SMEs contribute greatly to the growth of growth and poverty reduction (Ayandibu \& Houghton, 2017). Furthermore, SMEs are also significant for the formation of social capital in repairing the shattered social fabric in societies after disaster. In a wider context, strong SMEs can endorse national resilience to shocks by diversifying and expanding the local economy (Mavrodieva, Budiarti, Yu, Pasha, \& Shaw, 2019). 
Aderemi \& Ishak | Crowdfunding as an Alternative Mode of Financing Micro and Small Enterprises: A Proposed Qard-Al-Hasan Contract

\subsubsection{Qard al-Hasan as a Means of Financing}

Qard al-Hasan is made of two Arabic words: Qard and Hasan. As for Qard, literally, it means "to cut something off", referring a cut off from lender's assets by doling out the credit to the debtor. As for Hasan, it is originated from Ihsan which simply means benevolence or beautiful (Ariffin \& Adnan, 2012). As for technical meaning, Qard al-Hasan can be defined as a virtuous loan giving out with the clause of returning the principal sum to the owner in the same condition without any increase in the stipulated (Ariffin \& Adnan, 2012). In other words, it is the act in which the owner of an asset or money transfers his money or asset to with the clause of given it back to the owner in the same state and value as when it was initially received by the borrower from the owner (Abdul Rahman 2006). Therefore, it is understood that Qard al-Hasan is purely a non-profit loan which is aimed at helping the needy $n$ the society. However, Abdullah (2015) stressed that arguably, from the prism of Shari'ah, Qard-al-Hasan is neither certainly a transaction nor a gift, nonetheless, it occur within the two, which implies that Qard al-Hasan merge the two features together; the features of being a transaction and that of a gift.

In terms of its legitimacy, Qard al-Hasan has legal basis from Qur'an, Hadith and ljma' (Consensus of Scholars). As for the Qur'an, it is encouraged for humankind to do Qard al-Hasan (2:245,5:12, and 73:20). As for the Hadith, it was narrated by that Prophet (PBUH) said: "There is no Muslim who lend something to another Muslim twice, but it will be like giving charity once." (Ibn Majah, Hadith no 2430). As for ijma, all scholars have confirmed the permission of Qard al-Hasan practice, based on human nature that cannot live without helping each other (Kudamah, 1997).

In terms of its role as a financial instrument, Qard-al-Hassan has the potential to serve as a mechanism to assist the progress social and financial inclusion in the community. In the process of giving out credit to the poor, it can be introduced into the proper and standard monetary division as they are alleviated from poverty, thereby integrating them into the society. In light of this, Qard-al-Hassan tends to be a mechanism that aids in accomplishing social and economic justice as envisaged by Islamic economics. In fact, this can be comprehending with the aims of Qard-alHassan in terms of helping those who are in need, mobilizing treasure between societies, practicing a good deed, enabling the poor to come up with new occupations market and trade venture by utilizing their skills, expertise and merits and removing economic and social bias in the society 
Aderemi \& Ishak | Crowdfunding as an Alternative Mode of Financing Micro and Small Enterprises: A Proposed Qard-Al-Hasan Contract

(Junaidi, Lutfiah \& Adnan, 2017). However, there are some risk in Qard alHassan including risk of non-payment, risk of poor management, inflation risk and low risk of revenue (Khidher, 2014).

Since interest is highly prohibited in Islam, Qard-al-Hassan is given a preference and flexibility ( Abidin, Alwi \& Ariffin, 2011). Moreover, Qard-alHassan usually involves a simple procedure due to its nature which is small in size. Hence, this loan has easy access to capital contributors and borrowers due to its local standard (Iqbal \& Shafiq, 2015). At the same time, the creditor is encouraged to forego the payment if the borrower's effort to repay prove abortive due to economic difficulties. The Qur'an categorical state in numerous verses on the rate of return for Qard-al-Hassan (57:11, 18), (64:17), (2:245), providing believers with utmost certainty that they shall be rewarded in multitude in the present life and the hereafter. Therefore, the incentive for believers to initiate Qard-al-Hassan thus requires an attention for the reward promised in the hereafter as part of their long-term return. Consequently, Qard al-Hassan is regarded as a risk-free asset having perceived certain return in the believers' wealth portfolio (Sadr, 2014).

\section{Methodology}

In order to achieve the research objective, qualitative research was adopted by utilizing descriptive and inductive approach. Qualitative research methods are methods serving to demonstrate and intend to provide a profundity of knowledge, it centered around words, feelings, viewpoint and so on and they include interviews, focus groups, experiment (Creswell, 2012). To gather information this study utilized secondary data. According to Saunders \& Lewis (2012) the secondary data can be classified into three categories: documentary, multiple source and surveys, the researcher will review documentary secondary data such as books particularly Shariah sources; AlQur'an, Hadith and Fiq'h, published and journal as well as seminar proceeding, document, thesis and internet sources which are related to the scope of study. 
Aderemi \& Ishak | Crowdfunding as an Alternative Mode of Financing Micro and Small Enterprises: A Proposed Qard-Al-Hasan Contract

\section{Results and Analysis}

\subsection{Results}

\subsubsection{The proposed Qard al-Hasan-Based Crowdfunding Model}

As the current strategy of funding are not capable to fulfil the monetary need of micro and small enterprises, there is a necessity to look out for an additional dynamic and well-organized model of financing to help micro and small enterprises. A Qard al-Hasan crowdfunding model is proposed with the aim to be a viable alternative choice for the current micro and small enterprises strategy of financing as shown below.

In this study, the researcher propose the Qard-al-Hasan based crowdfunding model. This model merges the concept of crowdfunding for entrepreneurs using Shari'ah contract known as Qard-al-Hasan as an instrument. One of the characteristics of Qard-al-Hasan is that it flexible to assist the progress of any idea for the benefit of its assets without any pre-specified restrictions by the Shariah. From the prism of Shari'ah, a Qard-al-Hasan is neither certainly a transaction nor a gift, nonetheless, it occur within the two, which implies that Qard al-Hasan merge the two features together; the features of being a transaction and that of a gift (Abdullah, 2015). Subsequently Qard-al-Hasan is suitable and applicable to all purposes, its capital cost is very low and the borrower will face a very low risk, while the lender will face moderate risk (Widiyanto, Mutamimah, \& Hendar, 2011). The contract will be benevolent loan or Qard-al-Hasan which no interest shall be included. The management costs will be covered by donors and the cost will be charged with fixed amount instead of being in percentage rate. Next, in other for this model to be implemented, a platform is needed.

Qard-al-Hasan-based crowdfunding platform is created to endorse and support small and medium enterprises ventures that is in compliance with Shariah. As Muslims, its forbidden to engage in any transactions that contain elements of Gharar (Uncertainty), Riba (Interest) and Maysir (Gambling). As it is also illegal for them to take part in any transaction that consist of outlawed activities in Islam. For instance, any venture or trade that comprises pornography or alcohol must be avoided. In this case there is a need for Shariah compliant crowdfunding platform that will offer loan without engaging in Riba or any prohibited activities. Thus, the proposed Qard-al-Hasan-based crowdfunding platform offers and endorses projects and contracts that are in compliance with Shari'ah. 
Aderemi \& Ishak | Crowdfunding as an Alternative Mode of Financing Micro and Small Enterprises: A Proposed Qard-Al-Hasan Contract

In this proposed Qard al-Hasan-based crowdfunding there are four parties, namely:

1. Initiator of Project - which may consist of: individuals, association, and business;

2. Potential Funders;

3. Qard al-Hasan Crowdfunding platform (QCFP); and

4. Sharia Advisory.

\subsubsection{Explanation of the Four Parties}

I. Project Initiator (Entrepreneurs)

The entrepreneurs are the first actors as well as the initiators in crowdfunding mechanism. This are set of people who are financially les capable, but they possess skills of entrepreneurial and the group of people who are in need of capital to nurture their businesses. The participants of Qard-al-Hasan based crowdfunding would be the entrepreneurs who did not the viability to acquire the funds from other types of Islamic Crowdfunding (such as Mudarabah, Musharakah, Murabahah based crowdfunding) so they need to be assisted by using Qard-al-Hasan based crowdfunding.

\section{Potential Funders (Crowd)}

Crowd is the last actor and the most important actor among three actors. The crowd is a large group of ordinary people, who can take out some petty donations from their wealth to support the concepts they find promising. There are several names for the crowd: funders, investors, backers, or donors. The crowd will donate to fund the project within a certain time of period. The contract between the crowd and the platform is pure charity for the purpose of funding the entrepreneurs. The crowd will give a portion of the charity to pay the fee to the platforms under Wakalah contract. In this model, the crowd also represents those who are less fortunate financially.

\section{Qard al-Hasan-Based Crowdfunding Platform}

The platform provides an intermediate facility to act as an intermediary between a businessperson and potential crowdfunders. In this study, the proposed platform is also acting as a manager. The platform is based on Shariah, in which one of its duties is to ensure that the business idea presented or pitched to them is Shariah compliant. Any idea which passes 
Aderemi \& Ishak | Crowdfunding as an Alternative Mode of Financing Micro and Small Enterprises: A Proposed Qard-Al-Hasan Contract

the screening or due diligence process will be promoted to the crowd or the public.

\section{Board of Shariah}

The board of Shariah are the Shariah advisor provided by the proposed platform. The Shari'ah advisor have their responsibilities and objectives. They are to ensure that the idea posted by the entrepreneurs is complies with Shariah law (no alcohol, gambling, usury activities, speculation, Gharar, illegal items, etc.). A due diligence group ensures business owners are eligible for the service.

Illustration of Qard al-Hasan-Based crowdfunding platform:

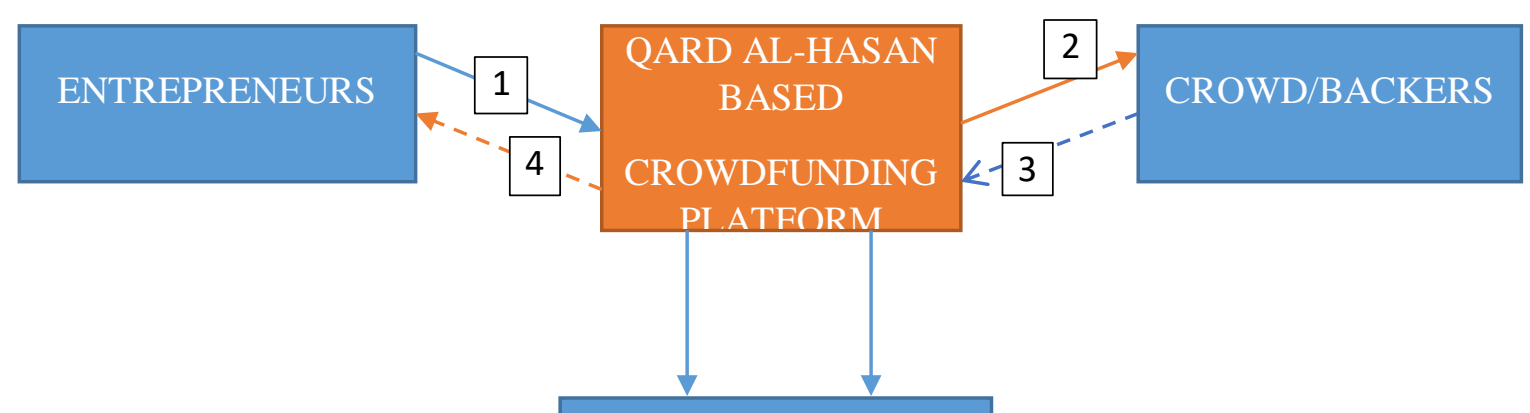

BOARD OF SHARIAH

SHARIAH ADVISOR

Figure 2. Qard al-Hasan-based Crowdfunding Framework

\section{Flow of the Figure}

1. The entrepreneurs pose or pitch their business ideas to the platform. In this stage, Shariah advisor appointed by the platform will ensure the idea complies with Shariah law (no alcohol, gambling, usury activities, speculation, Gharar, illegal items, etc.). A due diligence group ensures business owners are eligible for the service.

2. The platform promotes the selected ideas to the crowd or public as an agent

for the entrepreneurs. Because of the agency contract (Wakalah), the platform will get paid. It is known as the Wakalah contract that involves a fee (Wakalah bil Ujrah). The fee is paid using funds donated by the donor. 
Aderemi \& Ishak | Crowdfunding as an Alternative Mode of Financing Micro and Small Enterprises: A Proposed Qard-Al-Hasan Contract

3. The crowd or investors give donation or Sadaqah to the project via platform. After the funding period expired, the fund collected will be given to the entrepreneurs under the contract Qard al-Hasan between the entrepreneurs and the platform.

4. The entrepreneurs are obliged under $W a^{\prime} a d$ contract, to repay the loan without imposing any interest to the platform within a certain time frame. The contract will be incorporated with Kafalah to ensure that the entrepreneurs repay the loan at the given time. The amount of every repayment is small and affordable to the platform. During the project operation, Shariah advisor of the platform will monitor the project to always abide to the Shariah laws.

5. This proposed model will include a number of extra Islamic contracts such as Wakalah (Agency), Kafalah (Guarantee) and wa'ad (Promise). Wakalah is an agency contract between the funders and the platform. In this study, the proposed platform acts as a manager. As a Shariahcompliant platform, one of its duties is to ensure that the business idea presented or pitched to them is in compliance with Shariah. Since the platform aims to offer an Islamic product, it is recommending for the platform to employ a Shari'ah advisor in order to ensure that the proposed activities comply with Shariah laws. As well, the Shariah advisor ensures that to be approved ventures run in accordance with Shariah laws, in a way that any business ideas which transcend the screening or fair diligence procedure will then be publicized to the public or the crowd.

6. Thus, wa'ad contract will take place between the platform and ventures on compliance with the conditions specified and in line with Shariah. Wa'ad is considered as a monitoring tool on business or an ongoing project. Any misconduct committed by ventures will be penalized by the platform. A significant difference between this proposed model to the existing ones is that this Qard-al-Hasan-based model is purely meant for Small scale business and with no any interest involved.

Through the Qard al-Hasan-based crowdfunding model, entrepreneurs can do business while increasing their quality of life. In return, their businesses will help the community in creating jobs and facilities. 
Aderemi \& Ishak | Crowdfunding as an Alternative Mode of Financing Micro and Small Enterprises: A Proposed Qard-Al-Hasan Contract

\subsection{Analysis}

Convectional lending-based crowdfunding is based primarily on interest which is not in compliance with Shariah principle. However, in other to make a Shariah compliant crowd lending available, the platform has to depend on Islamic financial product and procedures to offer an alternative which will be interest free such the use of Qard al-Hasan which is currently being offered by the Pakistani-based Seed-out platform. From the Islamic finance standpoint, lending-based crowdfunding signify a substantial chance to provide the necessary opportunities from Islamic finance by linking the investment opportunities and benefits of social growth together in lieu of an extensive range of investors and entrepreneurs.

Qard al-Hasan is a virtuous loan without interest, in which it should be clear that the loan here is a good deed that does not have any benefit other than deepening the individual's spiritual standards and to realize the internal compatibility of the individual as well as to accomplish compatibility between individual and his community. Muslims are encouraged to borrow out their money to another Muslim brother or sister. It is clear that Islam is a religion that provides space and a solution to the difficulties faced by mankind, It is in line with the main principles underlying the contract of Qard al-Hasan which is ta'awun (helping each other) to ease the burden of those who are in distress and need (Zada \& Saba, 2013). However, Utomo et al. (2015) emphasized that Qard al-Hasan is very versatile in nature and can be used for financing for all sorts of consumption, production, services and debt activities, unlike the other products that may only suit certain types of contract. Therefore, Qard al-Hasan is suitable and applicable to all purposes in micro enterprises especially for the start-up, in which its capital cost is very low and its flexibility can support the progress of any idea for the benefit of its assets without any pre-specified restrictions by the Shari'ah.

The success of Qard al-Hasan as a means of MSMEs financing has been explained by Febianto \& Ashany (2012). Therefore, to adapt with modern means of channeling fund which is crowdfunding, Qard al-Hassan should be categorized under donation based crowdfunding, instead of lending crowdfunding because its motive is more to a charitable support for entrepreneurs. Wahjono et al. (2015) asserted that Islamic crowdfunding Qard-based is meant to finance a micro business with a loan which has to be refund at a given time. Interestingly, implication of Qard al-Hasan based crowdfunding model can be seen that the Qard al-Hasan and micro and small enterprises (MSEs) can incoherent with each other. MSEs are destined 
Aderemi \& Ishak | Crowdfunding as an Alternative Mode of Financing Micro and Small Enterprises: A Proposed Qard-Al-Hasan Contract

to boost the economy, and Qard al-Hasan can offer monetary support for MSEs.

The significant purpose of Qard-al-Hassan-Based crowdfunding is to assist the needy to be integrated into the economic system in a simplified and costeffective approach. In so far as the needy do not have any form of substantial material collateral, social capital tends to be the only collateral for issuing such credit. This equally creates an incentive for the needy to gain access to such credit for future sake. The implementation of Qard-al-Hassan-based crowdfunding is also associated to facilitating a harmonious life between the wealthy and the poor class in the society which result to a more cooperative, collaborative and generous society. In terms of society and economy, this model lay emphasis mostly on financing, it creates an atmosphere of improvement and divergence of economic motion. Also, it supports the stimulation of private ownership amongst micro and small enterprises. Qard al-Hasan crowdfunding model would be of great help to micro entrepreneurs in reaching out to financial services within their means. This model will provide seed funds in other to nurture micro and small enterprises sector and provide an access to funding for them. Additionally, this model will certainly mitigate unemployment by generating employment hopes and assist the poor micro and small entrepreneurs to acquire revenue and lastly the introduction of Qard-al-Hassan-based crowdfunding can effectively be used to alleviate poverty thereby facilitating an avenue of opportunities for the poor in order to create new labor market and business enterprise by utilizing such an advantage, potentials and expertise.

Subsequently, a significant different between this proposed crowdfunding model and previous one is this Qard al-Hasan-based crowdfunding model emphasis solely on micro and small enterprises as it is one of the core sectors to be focused on in eradicating unemployment within the society. Thus, this proposed crowdfunding model adopted Qard al-Hasan which is usually involves a simple procedure due to its nature which is small in size. This in essence will facilitate the process and period of approval rapidly and disbursement swiftly. Hence, the loan has easy access to capital contributors and borrowers due to its local standard. Lastly, being a new phenomenon, there is a very little study on crowdfunding from Islamic perspective generally. However, this study enhances the present literature in the areas of crowdfunding and Qard al-Hasan. It makes a first-hand literature on the avenue available for a productive exploitation of Qard al-Hasan for socioeconomic improvement. Owing to the newness of this field this study would be of great significance to the Islamic Financial Industry.

International Journal of Islamic Economics and Finance (IJIEF), 3(2), SI, 95-118 |111 
Aderemi \& Ishak | Crowdfunding as an Alternative Mode of Financing Micro and Small Enterprises: A Proposed Qard-Al-Hasan Contract

\section{Conclusion and Recommendation}

\subsection{Conclusion}

This study has revealed that micro, small and medium enterprises signify the core component of economy. However, these sectors are facing financial constraint in gaining access to capital from both government and private sources. As they are seen to be a risky sector in the market, and hence they imposed strict loan conditions on them such as raising loan requirement, limiting loan and increasing interest rates. Unluckily, most of this sector cannot survive these conditions, and therefore problem of financing remain unchanged. Thus, the present study proposes an idea of Qard al-Hasan based crowdfunding as to address this financial problem and improve their growth and role to the national revenue.

Qard al-Hasan based crowdfunding can be an alternative mode for financing micro and small scale enterprises. It can potentially yield higher return since it has no fixed interest return. However, several rules are embedded in Islamic crowdfunding in addition to the legal elements to ensure that all prohibited speculative intention and risks are ascertained. This is not only to protect the investors, but also to exercise social objectives. This model could be an alternative Shari'ah financing to traditional Islamic financial institutions as well as conventional crowdfunding for entrepreneurs so in return they can support socio economic development in the country. However, this model is associating with several risks including risk of non-payment, risk of miss management, and inflation risk. Nonetheless, these risks can be mitigated through proper reviewing by crowdfunding platforms as well as closely monitoring by them.

Finally, this study is dissimilar from previous studies for the reason that it provides useful insight on Qard al-Hasan-based crowdfunding based on the actual events. Other studies only suggest the concept or idea of Qard alHasan-based crowdfunding, but this study proves that the establishment and the implementation of the Qard al-Hasan-based crowdfunding as a means of financing micro and medium enterprises is possible and can be achieved while the risk associated to it can be mitigated. 
Aderemi \& Ishak | Crowdfunding as an Alternative Mode of Financing Micro and Small Enterprises: A Proposed Qard-Al-Hasan Contract

\subsection{Limitations and Recommendation}

In the light of the previous discussions, there are some recommendations for Islamic financial institution (IFI) and regulators. Islamic finance industry should put more focus on Islamic financial products and how they can be adopted using crowdfunding so that better and inexpensive Islamic financial product and services can be provided to customer and much more crowdfunding is where the future belongs in terms of financing small businesses. In addition to that Funding micro and small enterprises with crowdfunding could symbolizes a strong chance for Islamic finance in maximizing the elevation of its fundamental values concerning the development of its economic and social aspect. Also, Islamic financial institution should think of a way to manage and tackle the challenges and risks that are part of this means of financing, like cyber security, fraud and legal risk etc. As for the regulators the platforms that are Shari'ah compliance are need to be firmly regulated, so policy maker has to make sure to reduce the license fee and also simplify the procedure of getting a license by crowdfunding platforms.

Conjoining the fundamental principle of Shariah the concept of crowdfunding, together with the globalization and technology expansions, can signify a chance to contribute meaningfully to the enrichment of the business ecosystem in Islamic states. Finally, this paper is conceptual paper where there is no empirical analysis conducted. Hence in other to improve this study in the future, there are some suggestions for further researches in the following sentences: the developed model should be authenticated using interview and investigations to measure the intentions of the investor in using this model. Theories such as theory of philanthropy, theory of social influence and social capital theory can be very useful in this regard. 
Aderemi \& Ishak | Crowdfunding as an Alternative Mode of Financing Micro and Small Enterprises: A Proposed Qard-Al-Hasan Contract

\section{References}

Abdullah, M. (2015). Analysing the moral aspect of qard: a shariah perspective. International Journal of Islamic and Middle Eastern Finance and Management, 8(2), 171-184.

Abidin, A. Z., Alwi, N. M., \& Ariffin, N. M. (2011). A case study on the implementation of Qardhul Hasan concept as a financing product in Islamic banks in Malaysia. International Journal of Economics, Management and Accounting, 19(3), 81-100.

Achsien, I. H., \& Purnamasari, D. L. (2016). Islamic crowd-funding as the next financial innovation in Islamic finance: Potential and anticipated regulation in Indonesia. European Journal of Islamic Finance, 5.

Andreoni, J. (2006). Leadership giving in charitable fund-raising. Journal of Public Economic Theory, 8(1), 1-22.

Ariffin, N. M., \& Adnan, M. A. (2012). The perceptions of Islamic banker on qardhul hasan in Malaysia Islamic banks. Retrieved from www.googlescholar.com

Ayandibu, A. O., \& Houghton, J. (2017). The role of small and medium scale enterprise in local economic development (LED). Banach Journal of Mathematical Analysis, 11(2), 133-139.

Bagh, T., Arif, M., Liaqat, I., \& Razzaq, S. (2017). Impact of financial constraints on growth and development of small and medium enterprises in Sialkot Pakistan. International Journal of Financial Markets, 2(4), 131-141.

Bank, W. (2018). Small and medium enterprises (SMES) finance improving SMEs' access to finance and finding innovative solutions to unlock sources of capital. Retrieved March 26, 2020, from https://www.worldbank.org/en/topic/smefinance

Beaulieu, T., Sarker, S., \& Sarker, S. (2015). A conceptual framework for understanding crowdfunding. Communications of the Association for Information Systems, 37(1), 1.

Bilodeau, M., \& Slivinski, A. (1997). Rival charities. Journal of Public Economics, 66(3), 449-467.

Boylan, D. H., Nesson, D., \& Philipps, J. (2018). Understanding crowdfunding for business funding - a legal and platform review. Journal of Accounting \& Organizational Change., 14(3), 273-290.

Creswell, J. W. (2012). Educational research, planing, conducting and evaluating quantitative and qualitative research (Fourth Ed.). Boston, 
Aderemi \& Ishak | Crowdfunding as an Alternative Mode of Financing Micro and Small Enterprises: A Proposed Qard-Al-Hasan Contract

MA: Pearson Education, Inc.

Dar, M. S., Ahmed, S., \& Raziq, A. (2017). Small and medium-size enterprises in Pakistan: definition and critical issues. Pakistan Business Review, 19(1), 46-70.

Febianto, I., \& Ashany, A. M. (2012). The impact of Qardhul Hasan financing using Zakah funds on economic empowerment (Case study of Dompet Dhuafa, West Java, Indonesia). Asian Business Review, 1(1), 15-20.

Gbandi, E. C., \& Amissah, G. (2014). Financing options for small and medium enterprises ( SMEs ) in Nigeria. European Scientific Journal, 10(1), 327-340.

Hanim, M., Zurina, S., \& Muhammad, M. (2018). Islamic crowdfunding: Concepts, issues and opportunities in extending the boundaries of Islamic finance. M.A. USIM Press: USIM Malaysia, 4, 159-177.

Hassan, H. K. (2017). Crowdfunding from an Islamic finance perspective. Retrieved from https://ifikr.isra.my/

Hendratmi, A., Sukmaningrum, P. S., Ryandono, M. N.H, \& Ratnasari, R. T. (2019). The role of Islamic crowdfunding mechanisms in business and business development. Global J. Bus. Soc. Sci. Review, 7(1), 1-7.

Iqbal, Z., \& Shafiq, B. (2015). Islamic finance and the role of Qard-al-Hassan (Benevolent Loans) in enhancing inclusion: a case study of AKHUWAT. ACRN Oxford Journal of Finance and Risk Perspectives, $4(4), 23-40$.

Junaidi, Lutfiah, Z., \& Adnan, M. (2017). The effectiveness of interest-free loan financing (Qardhul Hasan) as the social implementer of Islamic bank to reduce poverty in Surakarta. Yustisia Jurnal Hukum, 6(2), 421-431.

Khalique, M., Isa, A. H. B. M., Nassir Shaari, J. A., \& Ageel, A. (2011). Challenges faced by the small and medium enterprise (SMEs) in Malaysia: An intellectual capital perspective. Interbational Journal of Current Research., 3(6), 398-401.

Khidher, M. (2014). Tamwil almuasasat almusagharat bisighat qard al hasan, dirasat halat sunduq alzakat liwilayat Biskra 2006-2012. University Mohamed Khigher-Biskra.

Kshetri, N. (2018). Informal institutions and internet-based equity crowdfunding. Journal of International Management, 24(1), 33-51. Retrieved from http://dx.doi.org/10.1016/j.intman.2017.07.001

Kudamah, I. 1997. (1997). Al-Mogni: Baabu Al-Qard. Riyad: Dar Aalama I kutub Riyad. 
Aderemi \& Ishak | Crowdfunding as an Alternative Mode of Financing Micro and Small Enterprises: A Proposed Qard-Al-Hasan Contract

Lambert, T., \& Schwienbacher, A. (2010). An empirical analysis of crowdfunding. Social Science Research Network 1578175, 1(23).

Lutfi, M. A., \& Ismail, M. A. (2016). Sadaqah -based crowdfunding model for microfinance and health care. Journal of Muamalat and Islamic Finance Research., 13(2), 31-51.

Ly, P., \& Mason, G. (2012). Individual preferences over development projects: Evidence from microlending on Kiva. Voluntas: International Journal of Voluntary and Nonprofit Organizations, 23(4), 1036-1055.

Marzban, S., Asutay, M., \& Boseli, A. (2014). Shariah-compliant crowdfunding: An efficient framework for entrepreneurship development in Islamic countries. Eleventh Harvard International Islamic Finance Form, Boston. Retrieved from www.researchgate.net

Massolution, C. L. (2015). Crowdfunding industry report. Http://Reports. Crowdsourcing. Org/Index. Php.

Mavrodieva, A. V., Budiarti, D. S., Yu, Z., Pasha, F. A., \& Shaw, R. (2019). Governmental incentivization for SMEs' engagement in disaster resilience in Southeast Asia. International Journal of Disaster Risk Management, 1(1), 32-50.

Ordanini, A., Miceli, L., Pizzetti, M., \& Parasuraman, A. (2011). Crowdfunding: Transforming customers into investors through innovative service platforms. Journal of Service Management, 22(4), 443-470.

Owens, J. V., \& Wilhelm, L. (2017). Alternative data transforming SME finance. (May), 1-88. Retrieved from http://documents.worldbank.org/curated/en/701331497329509915 /Alternative-data-transforming-SME-finance

Oyedepo, G., Duan, Y., Bentley, Y., \& He, Q. (2016). Analysis of factors affecting UK small and medium enterprises' corporate sustainability behaviour. In Proceedings of The 11th European Conference on Innovation and Entrepreneurship, 534-542. Retrieved from www.researchgate.net

Rahim, N. R., Kasmon, S. A., \& Taslim, K. N. (2018). Islamic philantropy and micro-crowdfunding fintech. Penerbit Press Universiti Teknologi Mara, 137-140.

Sadr, S. K. (2014). Qard I Hasan financing in Islamic bank. ISRA International Journal of Islamic Finance., 6(2).

Saiti, B., Musito, M. H., \& Yucel, E. (2018). Islamic crowdfunding: Fundamentals, developments and challenges. Islamic Quarterly, 62(3), 469-485.

Saunders, M. N., \& Lewis, P. (2012). Doing research in business \& 
Aderemi \& Ishak | Crowdfunding as an Alternative Mode of Financing Micro and Small Enterprises: A Proposed Qard-Al-Hasan Contract

management: An essential guide to planning your project. Pearson.

Schwienbacher, A., \& Larralde, B. (2012). Crowdfunding of small entrepreneurial ventures. SSRN Electronic Journal, 2010.

Thaker, M. A. M. T., Mohammed, M. O., Duasa, J., \& Abdullah, M. A. (2016). The behavioral intention of micro enterprises to use the integrated cash waqf micro enterprise investment (ICWME-I) model as a source of financing. Gadjah Mada International Journal of Business, 18(2), 111-130.

Thaker, M. A. M. T., Thaker, H. M. T., \& Pitchay, A. A. (2018). Modeling crowdfunders' behavioral intention to adopt the crowdfunding-waqf model (CWM) in Malaysia: The theory of the technology acceptance model. International Journal of Islamic and Middle Eastern Finance and Management., 11(2), 231-249.

Thaker, M. A. M. T. (2018). Modelling SMEs' behavioral intention to adopt Islamic crowdfunding-small and medium enterprises (ICSMEs) model as a source of financing in Malaysia. Journal of Islamic Monetary Economics and Finance., 4(2), 293-310.

Utomo, A. S., Maharani, N. K., \& Octavio, D. Q. (2015). Financial determinants of Qardhul Hasan financing growth: Evidence from Islamic banks in Indonesia. Global Review of Islamic Economics and Business, 3(1), 38-45.

Wahjono, S. I., Marina, A., \& Widayat. (2015). Islamic crowdfunding: Alternative funding solution. First World Islamic Social Science Congress (WISSC). Retrieved from www.researchgate.net

Widiyanto, W., Mutamimah, S., \& Hendar, H. (2011). Effectiveness of Qard alhasan financing as a poverty alleviation model. Economic Journal of Emerging Markets, 3(1), 27-42.

Wilson, K. E., \& Testoni, M. (2014). Improving the role of equity crowdfunding in Europe's capital markets. SSRN Electronic Journal,. Retrieved from http://ssrn.com/abstract $=2502280$

Yoshino, N. (2016). Major challenges facing small and medium-sized enterprises in Asia and solutions for mitigating them. In Tokyo: Asian Development Bank Institute. Retrieved from http://www.adb.org/publications/major- challenges-facing-smalland-medium-sized-enterprises-asia-and-solutions/

Zada, N., \& Saba, I. (2013). The potential use of Qard Hasan in Islamic microfinance. ISRA International Journal of Islamic Finance, 5(2), 153-163. 
Aderemi \& Ishak | Crowdfunding as an Alternative Mode of Financing Micro and Small Enterprises: A Proposed Qard-Al-Hasan Contract

This page is intentionally left blank 